\title{
Directional changes of the geomagnetic field in West Africa: Insights from the metallurgical site of Korsimoro
}

\author{
Fabio Donadini*, Vincent Serneels, Lisa Kapper, Akram El Kateb \\ University of Fribourg, Dept. of Earth Sciences, Chemin du Musée 6, 1700 Fribourg, Switzerland
}

\begin{abstract}
This work shows the first archeomagnetic directions from Western Africa measured on 32 iron smelting kilns dated between 650 and $1800 \mathrm{AD}$. The archeological excavation of the vast metallurgical site of Korsimoro established the existence of four distinct iron-smelting techniques. The time-frame of each technique could be clearly determined with radiocarbon dating. Many of the kilns investigated in this study could also be dated individually with residual charcoals found in their inside. The results indicate that the inclination of the field changed gradually from shallow normal to shallow reversed during 800 to $1300 \mathrm{AD}$, and then went back to shallow normal around 1600-1700 AD. The declination was instead stable around $10^{\circ} \mathrm{E}$ between 800 and $1400 \mathrm{AD}$, thereafter it started changing towards North. This trend correlates well with available secular variation curves from the Balkan and from Spain, and indicates that the field variation in West Africa was similar to the one in Europe.
\end{abstract}

\section{Introduction}

Archeomagnetism allows reconstructing the geomagnetic field changes during Holocene based on the remanent magnetization recorded by baked artifacts. The study of these changes can help understanding the dynamics of the core, where the field is generated. The outcome of the reconstruction in terms of global models (e.g. Korte et al., 2009, 2011; Korte and Constable, 2011; Licht et al., 2013), regional models (e.g. Pavón-Carrasco et al., 2009, 2014), or secular variation curves (e.g. Tema and Kondopoulou, 2011) is also widely used for dating purposes. Based on the mathematical approaches of Lanos (2004), Pavón-Carrasco et al. (2011) developed a tool that facilitates considerably the estimation of the date of an artifact based on a particular model or curve calculated at the artifact's location. One of the limitations of these reconstructions is due to the fact that most data cover the past $2000 \mathrm{yr}$ only, and are located in Europe, therefore hampering accurate dating outside of this timeframe or geographic boundary. In this sense several efforts have been made to find older artifacts (e.g. Carrancho et al., 2013; Kapper et al., 2014), or to widen the geographic coverage of the data (Hartmann et al., 2010, 2011; Goguitchaichvili et al., 2011). Studies covering the African continent are however very rare. In West Africa, for example, only one recent archeointensity study (Mitra et al., 2013) of ceramics from Mali and Senegal is available.

\footnotetext{
* Corresponding author.

E-mail addresses: fabio.donadini@gmail.com (F. Donadini) vincent.serneels@unifr.ch (V. Serneels), klkapper@gmail.com (L. Kapper).
}

This is one of the reasons why several features revealed by observatory and satellite data are not visible with archeomagnetic data. These include for example, equatorial flux spots (Jackson, 2003), likely representing the tops and bottoms of the columnar flow of the liquid iron; or the South Atlantic Magnetic Anomaly (SAMA); an intensity low located over the South Atlantic which has origin from a reversed flux patch bundle located under South Africa (e.g. Hulot et al., 2002).

The history of metallurgy in Western Africa spans back at least two millennia according to Bocoum (2002), and, based on the amount of slag-deposits found in certain regions, it represents one of the main economical activities. The early appearance and autochthony of iron metallurgy in West Africa is, at the moment, a matter of dispute in the scientific community (Bocoum, 2002; Killick, 2004; Alpern, 2005). During the first millennium AD, iron became common in the material culture of most of West African populations. Later on, about $800 \mathrm{AD}$, the scale of the production rose to a very high level and the African societies entered a true Iron Age as testified by numerous archeological remains (slag heaps and ruined furnaces). At the same time, the first organized states developed in the Sahelian area (for example the empires of Ghana, Mali). The understanding of the development of massive iron production and its trading is a key-question for inferring the global history of the area. About 30 districts with large scale iron production are identified from the Senegal valley to the Eastern Horn of Africa, however, only for a few cases detailed archeological data are available (Tylecote, 1982; de Barros, 1986; Dupré and Pinçon, 1997; Kiéthega, 2009; Robion-Brunner, 2010). 


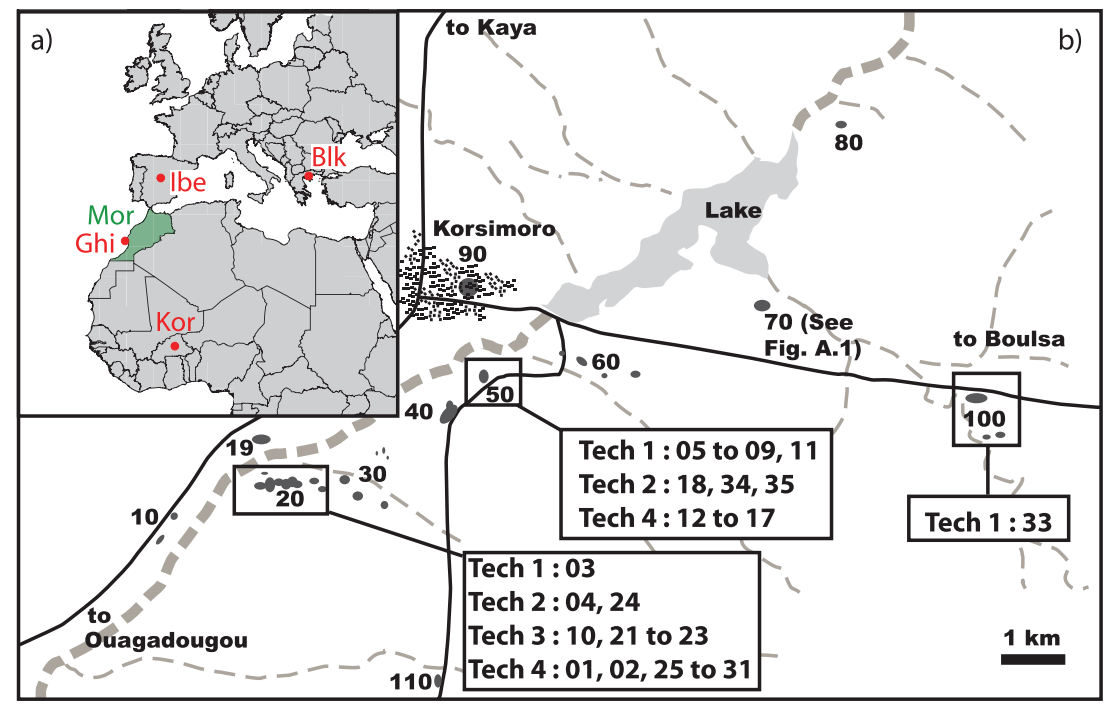

Fig. 1. a) Map of Africa and Europe showing the location of Korsimoro (Kor) along with the location with which we compare the magnetic data: Cape Ghir (Ghi), Morocco (Mor), Iberia (Ibe), and the Balkans (Blk). b) The metallurgical remains around the village of Korsimoro (Burkina Faso) spread over 10 km along the river (dashed line). Twelve sectors (numbered 10 to 110) with abundant remains are located. The boxes indicate the identification numbers of the kilns sampled from a particular sector and the technique (Tech) they belong to.

Table 1

Available radiocarbon ages. The table presents the context where the charred material was collected, the technique (Tech) and the sector (Sec) to which it is belonging. Beta Nr. represents the laboratory number (Beta Analytics), name indicates the kiln sampled for archeomagnetism. Age intervals are given as 2 sigma bounds. Uncalibrated

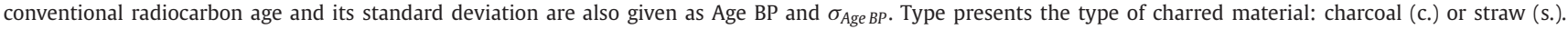

\begin{tabular}{|c|c|c|c|c|c|c|c|c|c|}
\hline Context & Tech & $\mathrm{Sec}$ & Beta Nr. & Name & $\begin{array}{l}\text { Age min } \\
\text { (Years AD) }\end{array}$ & $\begin{array}{l}\text { Age max } \\
\text { (Years AD) }\end{array}$ & $\begin{array}{l}\text { Age BP } \\
\text { (Years BP) }\end{array}$ & $\begin{array}{l}\sigma_{\text {Age BP }} \\
\text { (Years BP) }\end{array}$ & Type \\
\hline Kiln & $1 ?$ & 20 & 313120 & KRS03 & 780 & 970 & 1150 & 30 & c. \\
\hline Kiln & 1 & 50 & 316573 & KRS05 & 710 & 890 & 1210 & 30 & s. \\
\hline Kiln & 1 & 100 & 316575 & KRS33 & 660 & 780 & 1280 & 30 & s. \\
\hline Kiln & 2 & 26 & 313116 & KRS04 & 1030 & 1210 & 910 & 30 & c. \\
\hline Kiln & 2 & 50 & 372266 & KRS34 & 1270 & 1310 & 680 & 30 & c. \\
\hline Kiln & 2 & 50 & 316571 & KRS35 & 1025 & 1175 & 930 & 30 & c. \\
\hline Basis slag deposit & 2 & 26 & 313117 & & 1030 & 1220 & 900 & 30 & \\
\hline Basis slag deposit & 2 & 100 & 316574 & & 1050 & 1220 & 870 & 30 & \\
\hline Kiln & 3 & 20 & 316570 & KRS10 & 1285 & 1395 & 640 & 30 & c. \\
\hline Kiln & 3 & 20 & 372365 & KRS23 & 1410 & 1450 & 480 & 30 & c. \\
\hline Basis slag deposit & 3 & 20 & 13115 & & 1315 & 1430 & 550 & 30 & \\
\hline Basis slag deposit & 3 & 20 & 313121 & & 1440 & 1520 & 390 & 30 & \\
\hline Small kiln & 4 & 20 & 313119 & KRS01 & 1620 & 1660 & 280 & 30 & s. \\
\hline Small kiln & 4 & 20 & 313118 & KRSO2 & 1640 & 1670 & 240 & 30 & s. \\
\hline Small kiln & 4 & 20 & 372364 & & 1670 & 1780 & 150 & 30 & \\
\hline Occupation & $\leq 3$ & 50 & 316572 & & 640 & 675 & 1370 & 30 & \\
\hline Inhumation & & 100 & 372367 & & 900 & 1020 & 1050 & 30 & \\
\hline Forge & & & 313122 & & 1630 & 1670 & 260 & 30 & \\
\hline
\end{tabular}

The scope of this study was therefore to gather new reliable directional data from smelting kilns from the metallurgical site at Korsimoro (Burkina Faso, West Africa). The new magnetic data from West Africa is beneficial for refining the understanding of the global geomagnetic field dynamics during Holocene, and set a basis for novel West African secular variation curves. Further, the comparison of the directions, together with stratigraphic information and absolute dating, can help archeologists to define if certain kilns are contemporaneous.

\section{The smelting site of Korsimoro}

Korsimoro is located about $70 \mathrm{~km}$ North of the capital of Burkina Faso, Ouagadougou, about $12.79^{\circ} \mathrm{N}$ latitude and $1.09^{\circ} \mathrm{W}$ longitude. The metallurgical activity occurred in various sectors, spreading over an area of about $10 \mathrm{~km}$, and generally located along the river (Fig. 1). Individual sectors can reach up to $1 \mathrm{~km}$ in extension, and are well recognizable from satellite images, supporting the vastness of the metallurgical activity (Fig. A.1, Supplementary material). During two field campaigns, organized with the support of the Swiss-Liechtenstein Foundation for Archaeological Research Abroad (SLSA), sectors 20 and 50 were studied in detail (Fig. 1). The archeological excavation was carried out by swiss and local archeologists with the purpose of identifying the various techniques in use, the amount of slag production, and their chronology. At present four different smelting techniques have been recognized based on the grouping and typology of kilns, slag-deposits, and tuyeres (Serneels et al., 2011). Charred material (charcoal or burnt straw) was collected for radiocarbon analyses preferably from the bottom of excavated kilns or at the basis of the slag deposits. The results are reported in Table 1 and Fig. 2a. They indicate that the 4 techniques correspond to 4 successive chronological phases ranging between 650 and $1800 \mathrm{AD}$. Radiocarbon dates and stratigraphic constraints set the basis for assessing the age of each production phase (Serneels et al., 2013). Fig. 2b shows the evolution of the kilns' morphology in time and the associated technique, together with the amounts of slag produced (Fig. 2c). The gray shaded window in Fig. $2 b$ shows the preferred age range, whereas the white 


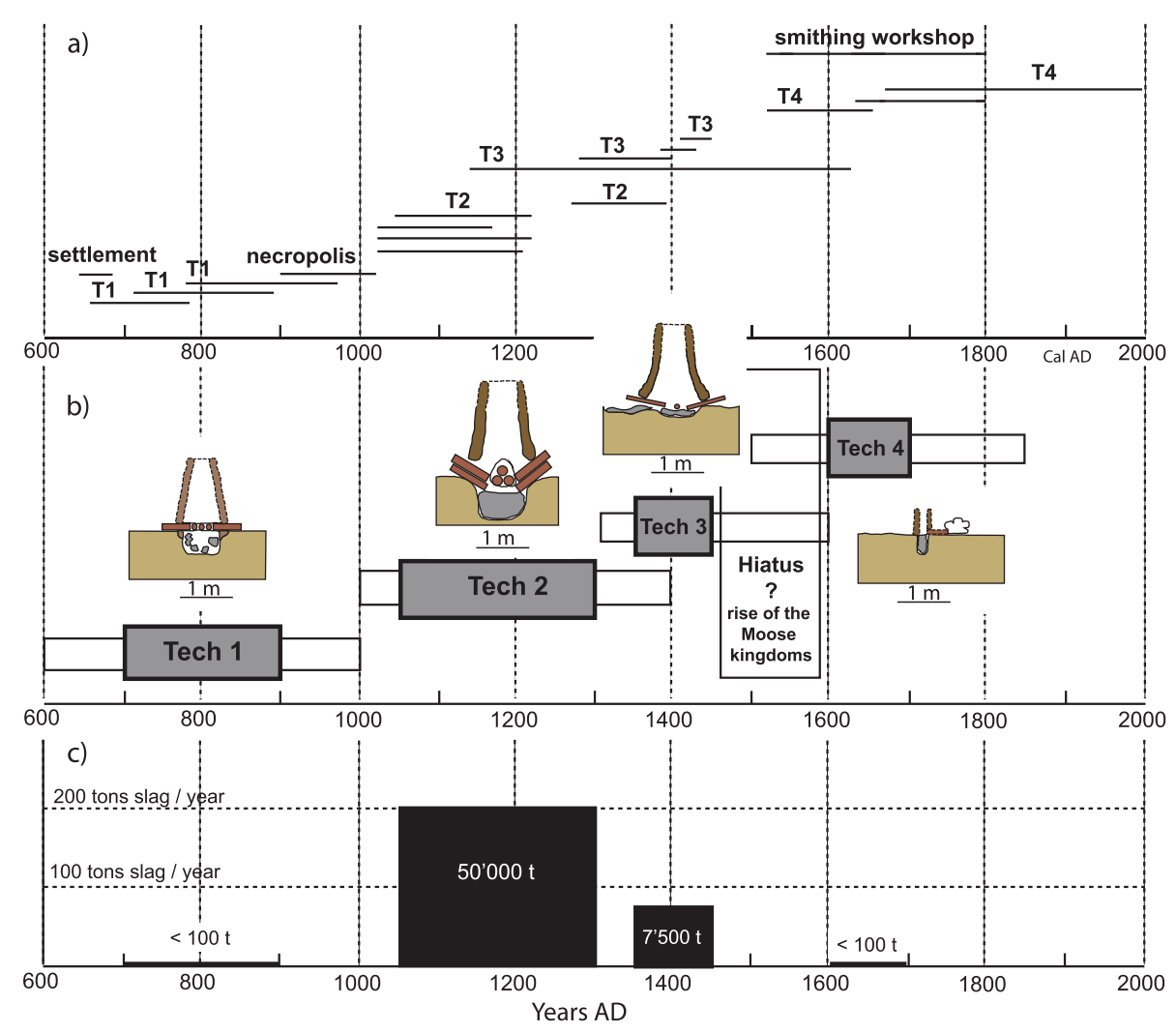

Fig. 2. Chronological frame of the metallurgical site of Korsimoro (Burkina Faso). a) Radiocarbon datings. b) Sketches and extents of the technological phases 1 to 4 . c) Estimated slag quantities for the different technological phases.

shaded box indicates its maximal extent (see Serneels et al., 2013 for details about these definitions).

Technique 1, dated between 650 and $950 \mathrm{AD}$, is characterized by series of about 10 aligned pits filled with slag-deposits. Each pit represents the base of a kiln that was used only one time (Fig. 3a). The absence of wall-remnants suggests that the shaft of the kiln was movable and it was displaced from pit to pit after each smelt. Similar methodologies are known in West-African metallurgy (Echard, 1968). Based on the volumetric production of slag (less than $500 \mathrm{~kg} / \mathrm{yr}$, corresponding to a net iron production of about $100 \mathrm{~kg} / \mathrm{yr}$ ), technique 1 represents a minor activity, aimed at producing iron for local use. The clusters of aligned kilns therefore would indicate smelting activities occurring on a regular basis (perhaps yearly) by groups of about 10 people. Remains related to the technique 1 are located in sectors $30,40,50$ and 100 . Kiln KRSO3 (sector 20) has a radiocarbon age (Beta Nr. 313120, Table 1) similar to that of technique 1 (sector 50 and 100). It was largely eroded and only a simple shallow bowl, lined with burnt clay and filled with metallurgical wastes, is preserved. Unfortunately, there is not enough information to relate this structure to a specific technique.

Based on field observation and volumetric calculations the main production happened within phase 2 (1100-1350 AD). In particular technique 2 , characteristic of phase 2 , is identified by large areas (up to $500 \mathrm{~m}^{2}$ ) covered by a slag layer of about $50 \mathrm{~cm}$ thickness, and indicate an annual production of $40000 \mathrm{~kg}$ of iron. The slag layer is punctuated with various smelting kilns, each of which reaching about $1 \mathrm{~m}$ in diameter (Fig. 3b). The kilns were used many times, as indicated by the remolding structures. The large production related to this phase indicates that during that period Korsimoro was a centre of excellence for iron production probably counting perhaps more than 1000 among artisans, smelters, lumberjacks, etc. Most of the annual production was most likely used within a larger region.
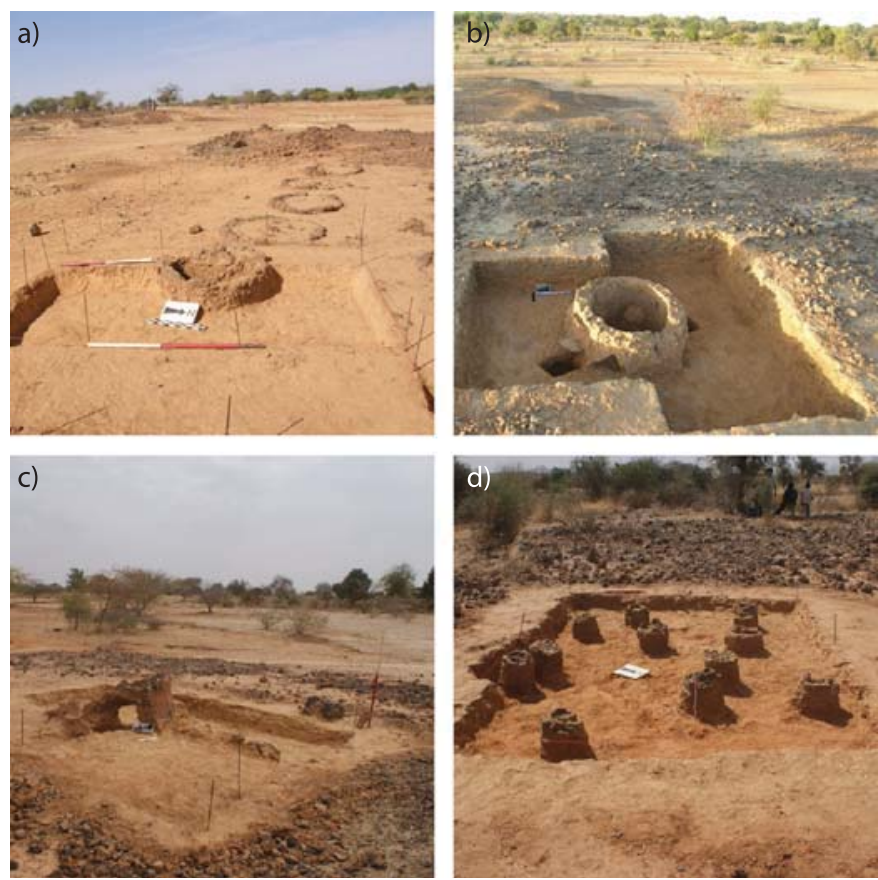

Fig. 3. Typical iron smelting furnace remains excavated at Korsimoro (Burkina Faso). a) Technique 1: Sector 50: alignment of single use slag pit furnaces. b) Technique 2: Sector 50: large reusable slag pit furnace. c) Technique 3: Sector 20: large reusable slag tapping furnace. d) Technique 4: Sector 20: cluster of very small slag pit furnaces.

Technique 3 (1350-1500 AD) can be generally observed at the periphery of the areas of technique 2 and introduces a major technological change with the tapping of the slag out of the furnace. It can be recognized by the annular pile of slag-deposits surrounding 
the kiln (Fig. 3c), which has an opening on one side to allow access to the kiln itself. It is not clear whether the positioning of the ring has a particular function, nevertheless it may have helped the draft of the shaft. Based on the volumetric calculations, the annual iron production corresponded to about $10000 \mathrm{~kg} / \mathrm{yr}$.

Finally, there is large a number (about 500) of tiny smelting kilns with about $30 \mathrm{~cm}$ diameter (Fig. 3d), clustered in groups over extended areas, which characterize technique 4 . This is the youngest of the techniques (1600-1700 AD), and represents again a minor activity based on the volumetric calculations (about $100 \mathrm{~kg} / \mathrm{yr}$ ). Although Kiéthega (2009) reported that similar ovens were used to refine the product obtained from the first smelting, the absence of large kilns of the same age let us exclude this hypothesis.

\section{Sampling, archeomagnetic and rock magnetic methods}

In total, 32 kilns were sampled (Fig. 1). We took seven to nine blocks from each structure, and oriented them using both a magnetic and a sun compass. The blocks were cut in cube specimens of $2 \mathrm{~cm}$ side at the facilities of the Univ. of Fribourg. Angles between magnetic north and sun shadow were measured by hand and the correction for local magnetic declination was calculated using the MagIC software of Tauxe et al. (2010). In general, these corrections ranged between 0 and $5^{\circ}$. Kilns sampled for archeomagnetic measurements were dated using the following hierarchy (cf. Table 1):

- combined radiocarbon age if more than one determination was available.

- radiocarbon age if the determination was associated to the kiln.

- radiocarbon age if the determination was from a similar kiln in the same context.

- technique age if no absolute value was available (see Fig. 2).

All magnetic samples were analyzed at the Laboratory for Natural Magnetism (LNM) of the ETH Zürich, Switzerland. Rock magnetic analyses included high-temperature magnetic susceptibility measurements using either an Agico KLY 2 or KLY 4 device, hysteresis and backfield measurements with a Princeton Vibrating Sample Magnetometer, and 3-axes Isothermal Remanent Magnetization (3IRM) experiments. Both thermal and alternating field demagnetization treatments were used to isolate the Characteristic Remanent Magnetization (ChRM). This was achieved using an ASC Scientific TSD48 oven and a 2G squid magnetometer.

\section{Rock magnetic results}

High temperature magnetic susceptibility were measured on 40 specimens (Fig. 4), whereas hysteresis loops were made on 58 specimens (Fig. A.2, Suppl. mat.). Furthermore, 16 three-axes Isothermal Remanent Magnetization (3-IRM) experiments were carried out (Fig. 5). Results are reported in Tables A.1 and A.2 (Suppl. mat.). In general, kilns belonging to techniques 1 and 4 , characterized by brown to black colored materials, present magnetite as main magnetic carrier, with typical Curie temperature around $580^{\circ} \mathrm{C}$ and hysteresis loops saturating at about $0.2 \mathrm{~T}$ (Fig. A.2 a, b, g, h; Suppl. mat.). Instead, kilns belonging to techniques 2 and 3 show colors ranging from red to brown. In general, red specimens show wasp waisted loops, characteristic of mixtures of high and low coercivity minerals. High temperature susceptibility curves and 3-IRM experiments reveal Curie temperatures of about 580 and $680^{\circ} \mathrm{C}$, and indicate the presence of both magnetite and hematite. Additionally, the 3-IRM experiments show a Curie temperature of $200^{\circ} \mathrm{C}$ associated with the high coercivity component (Fig. 5 and Table A.2, Suppl. mat.). Due to the reversibility
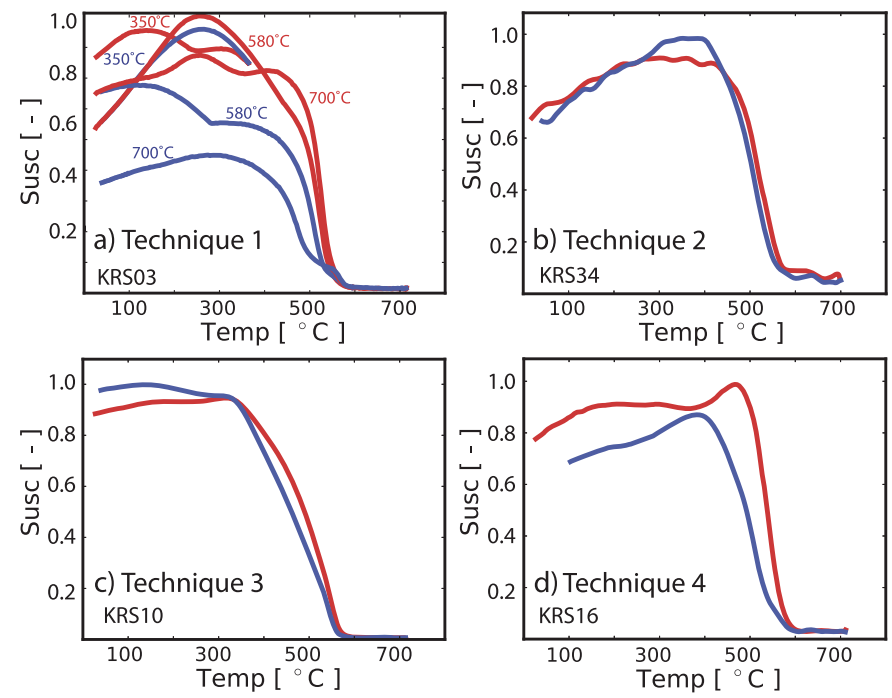

Fig. 4. High temperature susceptibility curves of four samples belonging to technique 1 to 4 (a to d). Red (blue) line represents the heating (cooling) curve. (For interpretation of the references to color in this figure legend, the reader is referred to the web version of this article.)
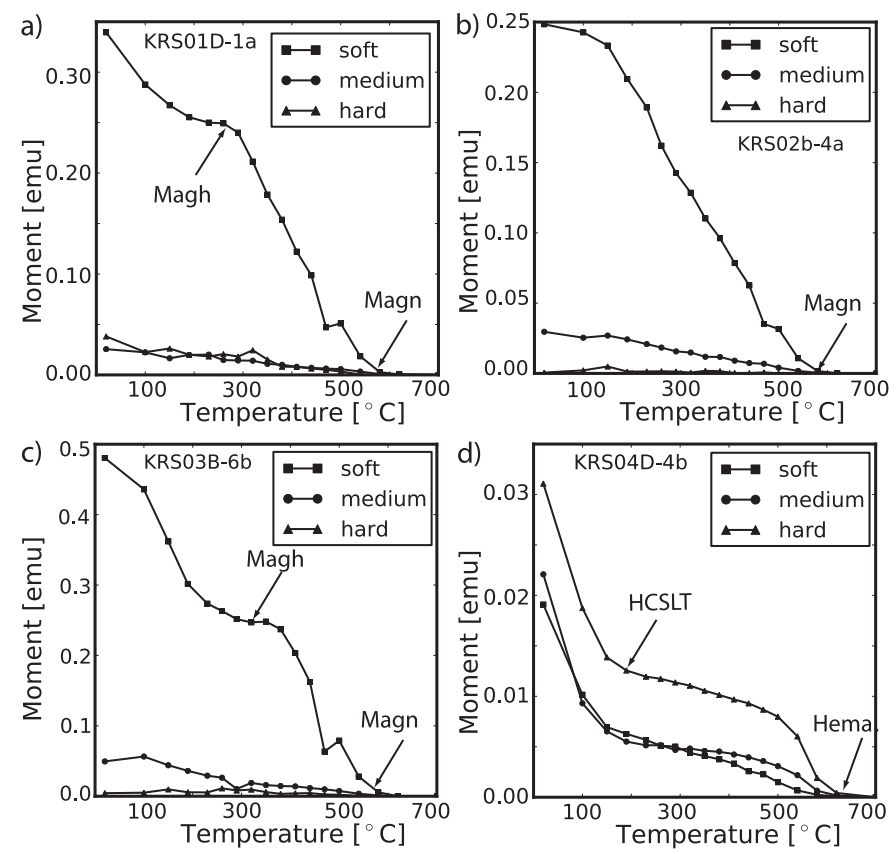

Fig. 5. Examples of three axes IRM demagnetizations after (Lowrie, 1990). Soft, medium, and hard axes are imparted an IRM of $0.2,0.46$, and $1 \mathrm{~T}$, respectively. Magnetic minerals are denoted as magnetite (Magn), hematite (Hema), maghemite (Magh), and High Coercivity Stable Low Temperature phase (HCSLT).

of most high temperature susceptibility curves of these specimens, we infer that HCSLT phase (McIntosh et al., 2007) is also present in these kilns.

\section{Directional results}

We analyzed 806 specimens belonging to the 29 kilns. Three structures belonging to technique 1 were not measured. In general, specimens show a well defined ChRM with little viscous overprint, which is removed by a $5 \mathrm{mT}$ alternating field or by a temperature of $100^{\circ} \mathrm{C}$. Typical Zidjerveld diagrams of the kilns are presented in Fig. 6.

Averages were calculated following the hierarchical approach (Lanos et al., 2005) and are presented in Table A.3 (Suppl. mat.); typical stereoplots of measurements that are representative for 

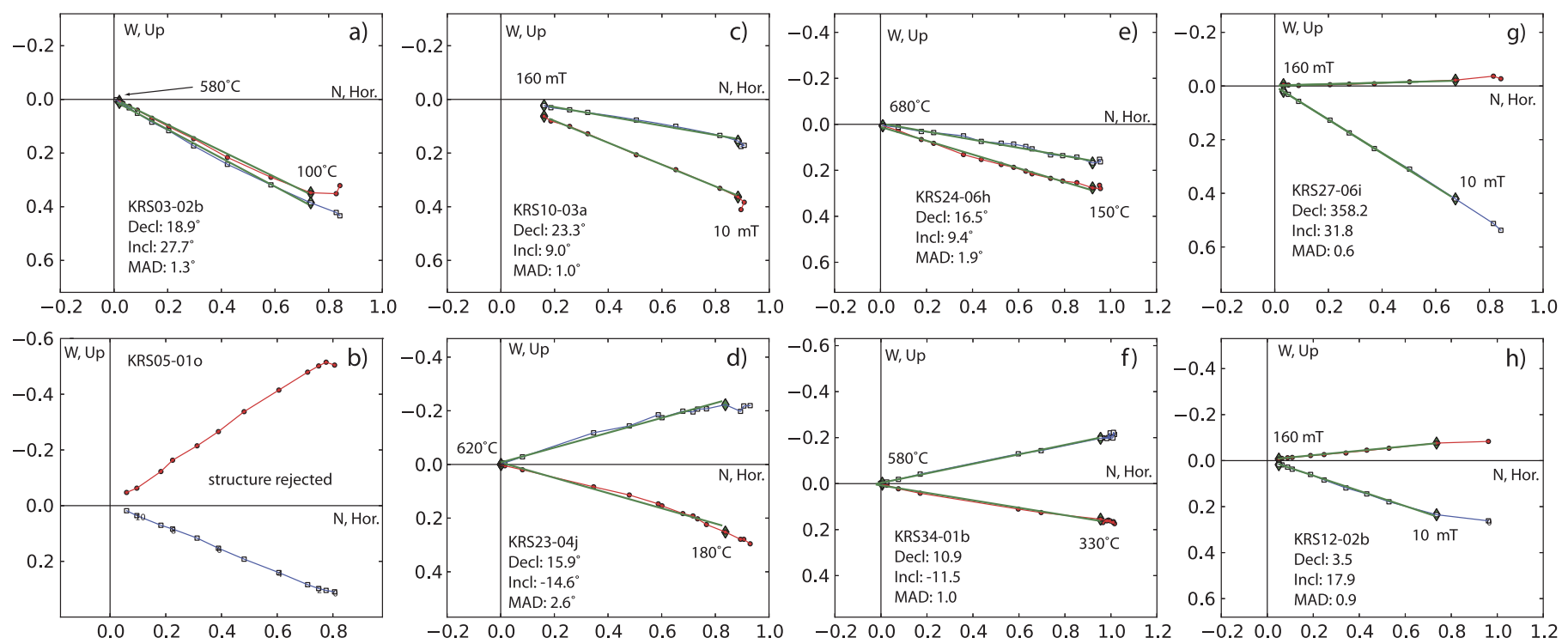

Fig. 6. Typical vector diagrams from samples belonging to technique 1 (a and b), technique 2 (c and d), technique 3 (e and f), and technique 4 (g and h). Declination (Inclination) is presented as a red (blue) line. Best fit direction as green line. (For interpretation of the references to color in this figure legend, the reader is referred to the web version of this article.)

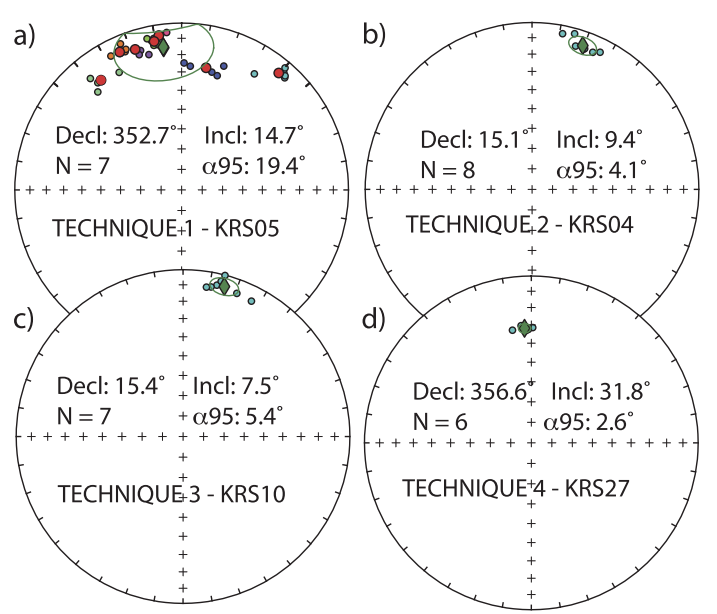

Fig. 7. Stereoplots showing typical measurements obtained from structures belonging to various techniques.

each technique ( 1 to 4 ) are shown in Fig. 7. Structures and samples yielding $\alpha_{95} \geq 6.5^{\circ} \mathrm{C}$ were rejected. In total 10 kilns did not yield reliable results.

All kilns belonging to technique 1 (KRS05-09, 11, and 33) yield clustered sample directions, however, kiln averages have large errors and were therefore rejected. Further, these averages have declinations ranging between NW and NE, and shallow inclinations, in agreement with expected values for the Holocene field in Burkina Faso. This observation indicates that the samples have moved slightly, but significantly, after acquiring the ChRM. Attempts to reconstruct original directions by rotating samples back in their original position have been successfully applied in other similar cases (e.g. Hoye, 1982). Such reconstructions imply that the movement is known to some extent, for example if the wall visibly collapsed in a certain fashion. The kilns analyzed here, however, show random movements, and attempts to reorient the samples failed. It is possible that while moving the shaft from one kiln to the next one, the upper part of the wall got displaced. One way to test that would be a sampling at the base of the structure. Kiln KRSO3 (sector 20) has a radiocarbon age similar to that of technique 1 (sectors 50 and 100 ), however it is an isolated kiln with walls. In this case a hor- izontal rotation of two samples around their vertical axis by $15^{\circ}$ was evident, and so it was taken into account. The corrected direction has an average declination of $13.8^{\circ}$ and inclination of $22.8^{\circ}$, with $\alpha_{95}$ of $6.2^{\circ}$.

The five kilns belonging to technique 2 (1100-1300 AD) show in general N-NW declinations, and shallow normal (KRS04 and KRS24) to shallow reversed (KRS18, 34, and 35) inclinations. Four kilns (KRS10, 21, 22, and 23) belong to technique 3 (1300-1500 AD). The directions of these kilns show N-NE to N-NW declinations and shallow normal to reversed inclinations. Finally, all the kilns belonging to technique 4 (1600-1800 AD) show steeper inclination ranging between 20 and $30^{\circ}$ and declinations ranging between $\mathrm{N}$ and $\mathrm{NE}$ directions. Five of these structures (KRS01, KRS02, KRS15, KRS29, and KRS31) were rejected due to their $\alpha_{95} \geq 6.5^{\circ}$.

\section{Discussion}

In general there is a good agreement between the results from neighbor kilns belonging to the same technique. For example, KRS04 (radiocarbon dated) and KRS24 (not dated by radiocarbon) belong to the same group of kilns and lie about $5 \mathrm{~m}$ apart from each other. The similar directions indicate that the two structures are contemporaneous. For this reason we use the same age for both. In some other cases discrepancies can be observed. For example, KRS18 (undated), KRS34 (dated) and KRS35 (dated) also belong to the same group of kilns, confined by a layer of slagdeposits within an area of about $4000 \mathrm{~m}^{2}$ (sector 50). Based on the undistinguishable magnetic directions, the three kilns seem to be contemporaneous. However the radiocarbon date of KRS34 indicates an age about $200 \mathrm{yr}$ younger than KRS35. There are two possible reasons to explain this discrepancy. The first one is related to the process of sampling the charcoals. The charcoal samples of KRS34 were taken from the filling of the furnace above the slag of the last smelt. It is believed to be contemporaneous of the last smelt and of the magnetic direction. On the contrary, the charcoals of KRS35 were collected at the very bottom of the furnace. This date may be related to an iron production predating the last smelt, and so the radiocarbon age would be older than the magnetic direction. The second reason may be related to the old wood effect (e.g. Killick, 1987). One peculiarity of Sahelian wood is the ab- 


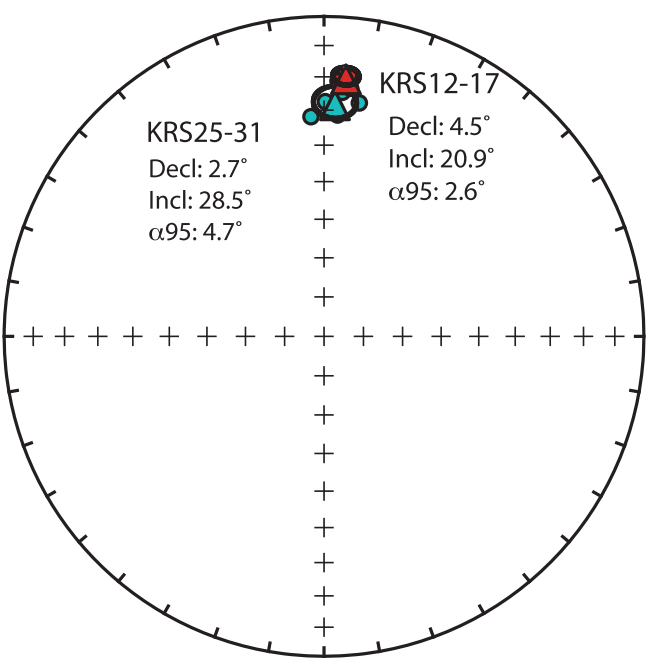

Fig. 8. Stereoplot showing the averages of the Technique 4 structures belonging to sector 20 (samples: cyan circles, site; cyan triangle), and to sector 50 (samples: red circles, site; red triangle). (For interpretation of the references to color in this figure legend, the reader is referred to the web version of this article.)

sence of annual growth-lines, which hampers the determination of its "true" age. Nevertheless it is unlikely that trees were preserved for several centuries (as suggested by the radiocarbon dates) because termites are quite active in the area.

Kilns KRS21 (undated) and 22 (undated) are separated by about $10 \mathrm{~m}$, however, they probably belong to two different stratigraphic units. In fact, KRS21 lied on top of a fluvial terrace, whereas KRS22 on its slope, about $1.5 \mathrm{~m}$ below KRS21. Based on this observation KRS22 should be older than KRS21. From a morphological point of view KRS21 clearly belongs to technique 3 based on its topology, whereas the large erosion hampered a clear assessment for KRS22. The different magnetic declinations support the idea that these two kilns are not contemporaneous. The data of KRS22 match with the Balkan curve at around $1100 \mathrm{AD}$, at the time of the peak production during the chronological phase 2 . Due to the large distance between the SV curve and Korsimoro, however, large relocation errors may be expected.

The kilns belonging to technique 4 are located in two distinct sectors (227 and 54). KRS1 and 2 (both dated, sector 227) are closely related in the field and must be of the same age. They are part of one single alignment and were probably used during the same production season. A third furnace from this alignment was dated (Beta Nr. 372364, cf. Table 1). Taken together these three dates give a very short range of common ages: $1657.5 \pm 12.5 \mathrm{AD}$. Unfortunately no directions from these two kilns could be retained. Furnaces KRS25 to 31, also belonging to sector 227, were collected about $10 \mathrm{~m}$ apart of KRS1 and 2 and yield clustered directions (declination: $2.7^{\circ}$, inclination: $28.5^{\circ}, \alpha_{95}: 4.7^{\circ}$, Fig. 8). Based on the organization of the kiln cluster, it is highly probable that they have similar ages as KRS1 and 2. For this reason we propose the age range between 1600 and $1700 \mathrm{AD}$. Undated kilns belonging to technique 4 were also sampled in sector 54 (KRS12 to 17). These kilns yield an average declination of $4.5^{\circ}$, an inclination of $20.9^{\circ}$ and a smaller $\alpha_{95}$ of $2.6^{\circ}$. Compared with the directions from sector 227 they show a slightly shallower inclination (although statistically indistinguishable), and may therefore indicate a slightly different age. For these latter kilns we propose an age range between 1500 and 1800 AD.

Fig. 9 shows the secular variation in terms of declination and inclination at Korsimoro. The averages of the structures reported in Table A.3 are shown as black circles along with the CALS3K.4 model as yellow line (Korte and Constable, 2011) and with the Balkan curve relocated at Korsimoro in red (Tema and Kondopoulou, 2011). Although from a distant region, the Balkan curve is the most complete and detailed paleosecular variation curve. Additionally the Spanish reference curve of Gomez-Paccard et al. (2006), located about $3000 \mathrm{~km}$ North of Burkina Faso, is presented as a green line. Available data from Northwest-
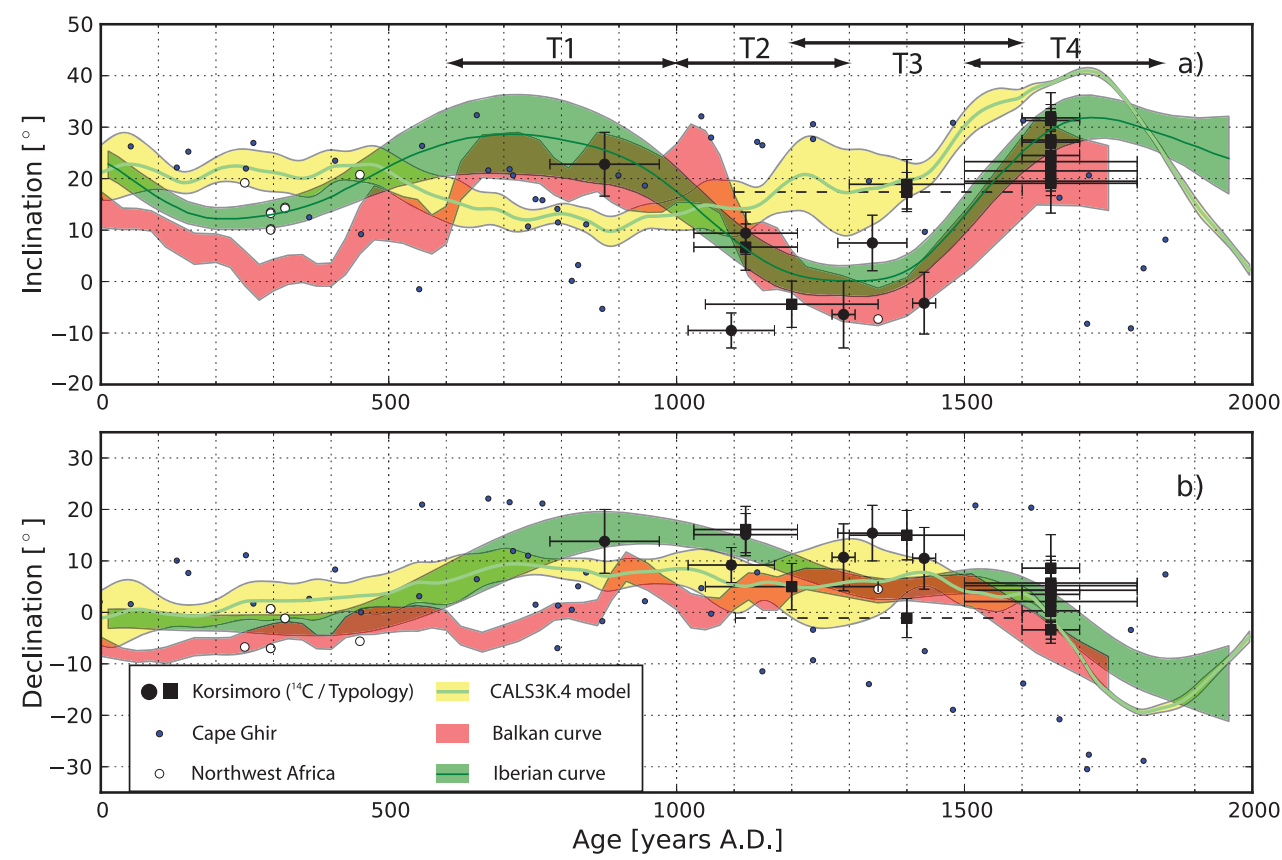

Fig. 9. Secular variation at Korsimoro. The data from this study are shown as black circles (radiocarbon ages) and black squares (typological date). The dashed error bar of kiln KRS22 indicates that its age cannot be determined with certainty. The CALS3K.4 model as yellow line (Korte and Constable, 2011), the Balkan curve in red (Tema and Kondopoulou, 2011), and the Spanish curve of Gomez-Paccard et al. (2006) as a green line. Available data from Northwestern Africa (Morocco) are also shown as white circles (Kovacheva, 1984; Thellier and Thellier, 1959; Najid, 1987; Casas et al., 2008; Gomez-Paccard et al., 2012). Marine sediment data from Cape Ghir (Bleil and Dillon, 2008) are indicated as blue circles. All data are relocated to Korsimoro. Thecniques (T1 to T4) age spans are indicated using double arrows. (For interpretation of the references to color in this figure legend, the reader is referred to the web version of this article.) 
ern Africa (Morocco) are also shown as white circles (Kovacheva, 1984; Thellier and Thellier, 1959; Najid, 1987; Casas et al., 2008; Gomez-Paccard et al., 2012).

Marine sediment data from Cape Ghir (Bleil and Dillon, 2008), about $2300 \mathrm{~km}$ north of Korsimoro, are indicated as blue circles. Compared to our data, the CALS3k.4 model does not show a minimum in inclination around 1250 AD. Instead, it follows the trend of the neighbor marine sediment data relocated at Korsimoro. On the other hand, the Balkan curve and the Spanish data relocated at Korsimoro appear to agree well with our dataset. This comparison suggests that long term trend of the geomagnetic field between 1000 and 1600 AD was similar in Europe and West Africa.

\section{Conclusions}

The data obtained in this study show that smelting kilns used for iron production can be used for archeomagnetic investigations, and sets the basis for the construction of a secular variation curve in West Africa. The comparison of directions between neighbor kilns also helps clarifying their degree of contemporaneity. The comparison of the West African data with European studies suggests that the long term trend of the field between 1000 and 1500 AD was very similar.

\section{Acknowledgements}

This work was supported by an SNF grant 105213_144102. The field campaign was carried out within the project Origine et dévéloppement de la métallurgie du fer au Burkina Faso et en Côte d'Ivoire supported by the SLSA Foundation. We are also most grateful to two anonymous reviewers for the detailed comments that led us to significantly improve the manuscript.

\section{Appendix A. Supplementary material}

Supplementary material related to this article can be found online at http://dx.doi.org/10.1016/j.epsl.2015.08.030.

\section{References}

Alpern, S., 2005. Did they or didn't they invent it? Iron in sub-Saharan Africa. Hist. Afr. 32, 41-94.

Bleil, U., Dillon, M., 2008. Holocene Earth's magnetic field variations recorded in marine sediments of the NW African continental margin. Studia Geophys. Geodet. 52, 133-155.

Bocoum, H., 2002. Aux origines de la métallurgie du fer en Afrique, Une ancienneté méconnue. UNESCO, Paris.

Carrancho, A., Villalain, J., Pavón-Carrasco, F., Osete, M., Straus, L., Verges, J., Carretero, J., Angelucci, D., Gonzalez-Morales, D., 2013. First directional European palaeosecular variation curve for the Neolithic based on archaeomagnetic data. Earth Planet. Sci. Lett. 380, 124-137.

Casas, L., Brianso, J., Alvarez, A., Benzzi, K., Shaw, J., 2008. Archeomagnetic intensity data from the Saadien Tombs (Marrakesh, Morocco), late 16th century. Phys. Chem. Earth 33, 474-480.

de Barros, P., 1986. Bassar: a quantified, chronologically controlled, regional approach to a traditional iron production centre in West Africa. Africa 56, 148-174.

Dupré, M., Pinçon, B., 1997. Métallurgie et Politique en Afrique: Deux Mille Ans sur les Plateaux Batéké. L'Harmattan, Paris.

Echard, N., 1968. Noces de feu. Motion picture $16 \mathrm{~mm}$. Available on purchase from CNRS Paris.

Goguitchaichvili, A., Greco, C., Morales, J., 2011. Geomagnetic field intensity behavior in South America between $400 \mathrm{AD}$ and $1800 \mathrm{AD}$ : first archeointensity results from Argentina. Phys. Earth Planet. Inter. 186, 191-197.

Gomez-Paccard, M., Chauvin, A., Lanos, P., McIntosh, G., Osete, M., Catanzariti, G., Ruiz-Martínez, V., Nuñez, J., 2006. First archaeomagnetic secular variation curve for the Iberian Peninsula: comparison with other data from western Europe and with global geomagnetic field models. Geochem. Geophys. Geosyst. 7, Q12001.

Gomez-Paccard, M., McIntosh, G., Beamud, A.C.E., Pavón-Carrasco, F., Thiriot, J., 2012. Archaeomagnetic and rock magnetic study of six kilns from North Africa (Tunisia and Morocco). Geophys. J. Int. 189, 169-186.
Hartmann, G., Genevey, A., Gallet, Y., Trindade, R., Etchevarne, C., Goff, M.L., Afonso, M., 2010. Archeointensity in Northeast Brazil over the past five centuries. Earth Planet. Sci. Lett. 296 (3-4), 340-352.

Hartmann, G., Genevey, A., Gallet, Y., Trindade, R., Le Goff, M., Najjar, R., Etchevarne, C., Afonso, M., 2011. New historical archeointensity data from Brazil: evidence for a large regional non-dipole field contribution over the past few centuries. Earth Planet. Sci. Lett. 306 (1-2), 66-76.

Hoye, G., 1982. A magnetic investigation of kiln wall distortion. Archaeometry 24, 80-84.

Hulot, G., Eymin, C., Langlais, B., Mandea, M., Olsen, N., 2002. Small-scale structure of the geodynamo inferred from Oersted and Magsat satellite data. Nature 416, 620-623.

Jackson, A., 2003. Intense equatorial flux spots on the surface of the Earth's core. Nature 424, 760-763.

Kapper, L., Donadini, F., Mauvilly, M., Panovska, S., Hirt, A., 2014. Mid-European geomagnetic field variations in the Holocene: new high quality data of burned sediments for geomagnetic field models. Geophys. J. Int. 198, 1208-1221.

Kiéthega, J., 2009. La métallurgie lourde du fer au Burkina Faso, une technologie a l'époque précoloniale. Karthala, Paris.

Killick, D., 2004. What do we know about African iron working? J. Afr. Archaeol. 2, 97-112.

Killick, K., 1987. On the dating of African metallurgical sites. Nyame Akuma 28, 29-30.

Korte, M., Constable, C., 2011. Improving geomagnetic field reconstructions for 0-3 ka. In: Proceedings of the 12th Symposium of SEDI. Phys. Earth Planet. Inter. $188,247-259$

Korte, M., Constable, C., Donadini, F., Holme, R., 2011. Reconstructing the Holocene geomagnetic field. Earth Planet. Sci. Lett. 312 (3), 497-505.

Korte, M., Donadini, F., Constable, C., 2009. Geomagnetic field for 0-3 ka: 2. A new series of time-varying global models. Geochem. Geophys. Geosyst. 10, Q06008.

Kovacheva, M., 1984. Some archaeomagnetic conclusions from three archaeological localities in North-West Africa. C. R. Acad. Bulgare Sci. 37, 171-174.

Lanos, P., 2004. Bayesian inference of calibration curves: application to archaeomagnetism. In: Buck, C., Millard, A. (Eds.), Tools for Constructing Chronologies: Crossing Disciplinary Boundaries. Springer-Verlag, London, pp. 43-82.

Lanos, P., LeGoff, M., Kovacheva, M., Schnepp, E., 2005. Hierarchical modelling of archaeomagnetic data and curve estimation by moving average technique. Geophys. J. Int. 160, 440-476.

Licht, A., Hulot, G., Gallet, Y., Thébault, E., 2013. Ensembles of low degree archeomagnetic field models for the past three millennia. Phys. Earth Planet. Inter. 224, 38-67.

Lowrie, W., 1990. Identification of ferromagnetic minerals in a rock by coercivity and unblocking temperature properties. Geophys. Res. Lett. 2, 159-162.

McIntosh, G., Kovacheva, M., Osete, M.-L., Casas, L., 2007. Widespread occurrence of a novel high coercivity, thermally stable, low unblocking temperature magnetic phase in heated archeological material. Geophys. Res. Lett. 34, L21302.

Mitra, R., Tauxe, L., McIntosh-Keech, S., 2013. Two thousand years of archeointensity from West Africa. Earth Planet. Sci. Lett. 364, 123-133.

Najid, D., 1987. Palaeomagnetic studies in Morocco. PhD thesis. University of Newcastle upon Tyne, United Kingdom.

Pavón-Carrasco, F., Osete, M., Torta, M., Gaya-Piqué, L., 2009. A regional archeomagnetic model for Europe for the last 3000 years, SCHA.DIF.3K: applications to archeomagnetic dating. Geochem. Geophys. Geosyst. 10, Q03013.

Pavón-Carrasco, F.J., Osete, M.L., Torta, J.M., Santis, A.D., 2014. A geomagnetic field model for the Holocene based on archaeomagnetic and lava flow data. Earth Planet. Sci. Lett. 388, 98-109.

Pavón-Carrasco, F.J., Rodríguez-Gonzalez, J., Osete, M.L., Torta, J.M., 2011. A Matlab tool for archaeomagnetic dating. J. Archaeol. Sci. 38 (2), 408-419.

Robion-Brunner, C., 2010. Forgerons et sidérurgie en pays Dogon; vers une histoire de la production du fer sur le plateau de Bandiagara (Mali) durant les empires précoloniaux. J. Afr. Archaeol. Monogr. Ser. 3. Frankfurt am Main.

Serneels, V., Donadini, F., Timpoko Kienon-Kaboré, H., Koté, L., Kouakou Kouassi, S., Ramseyer, D., Simporé, L., 2013. Origine et développement de la métallurgie du fer au Burkina Faso et en Côte d'Ivoire. Avancement des recherches en 2013 et quantification des vestiges de Korsimoro. SLSA Rapport Annuel. Schweizerisch Liechtensteinische Stiftung für Archäologische Forschungen im Ausland, pp. 65-112.

Serneels, V., Timpoko Kienon-Kaboré, H., Koté, L., Kouakou Kouassi, S., Ramseyer, D., Simporé, L., 2011. Origine et développement de la métallurgie du fer au Burkina Faso et en Côte d'Ivoire. Premier résultats sur le site sidérurgique de Korsimoro (Sanmatenga, Burkina Faso. SLSA Rapport Annuel. Schweizerisch Liechtensteinische Stiftung für Archäologische Forschungen im Ausland, pp. 23-54.

Tauxe, L., Butler, R., Banerjee, S., van der Voo, R., 2010. Essentials of Paleomagnetism. University of California Press, San Diego.

Tema, E., Kondopoulou, D., 2011. Secular variation of the Earth's magnetic field in the Balkan region during the last eight millennia based on archaeomagnetic data. Geophys. J. Int. 186 (2), 603-614.

Thellier, E., Thellier, O., 1959. Sur l'intensité du champ magnétique terrestre dans le passé historique et géologique. Ann. Geophys. 15, 285-376.

Tylecote, R., 1982. Metal working at Meroe, Sudan. In: Meroïtic Studies. Meroïtica 6, $29-42$ 